\title{
Hepatitis $C$ virus pharmacogenomics in Latin American populations: implications in the era of direct-acting antivirals
}

This article was published in the following Dove Press journal:

Pharmacogenomics and Personalized Medicine

28 March 2017

Number of times this article has been viewed

\author{
Julieta Trinks ${ }^{1,2}$ \\ Mariela Caputo ${ }^{2,3}$ \\ María L Hulaniuk' \\ Daniel Corach ${ }^{2,3}$ \\ Diego Flichman ${ }^{2,4}$
}

'Basic Science and Experimental Medicine Institute (ICBME), University Institute of the Italian Hospital of Buenos Aires, ${ }^{2}$ Scientific and Technological National Research Council (CONICET), ${ }^{3}$ Servicio de Huellas Digitales Genéticas, Facultad de Farmacia y Bioquímica, ${ }^{4}$ Cátedra de Virología, Facultad de Farmacia y Bioquímica, Universidad de Buenos Aires, Buenos Aires, Argentina
Correspondence: Julieta Trinks Instituto de Ciencias Básicas y Medicina Experimental (ICBME), Instituto Universitario del Hospital Italiano de Buenos Aires, Potosí 4240, CII 99 ACL Buenos Aires, Argentina Tel +54 I I 49590200 ext 495 I Fax +54 II 49590200 ext 4II I5 Email julieta.trinks@hospitalitaliano.org.ar

\begin{abstract}
In recent years, great progress has been made in the field of new therapeutic options for hepatitis $\mathrm{C}$ virus (HCV) infection. The new direct-acting antiviral agents (DAAs) represent a great hope for millions of chronically infected individuals because their use may lead to excellent cure rates with fewer side effects. In Latin America, the high prevalence of HCV genotype 1 infection and the significant association of Native American ancestry with risk predictive single-nucleotide polymorphisms (SNPs) in IFNL4 and ITPA genes highlight the need to implement new treatment regimens in these populations. However, the universal accessibility to DAAs is still not a reality in the region as their high cost is one of the major, although not the only, limiting factors for their broad implementation. Therefore, under these circumstances, could the assessment of host genetic markers be a useful tool to prioritize DAA treatment until global access to these new drugs can be achieved? This review will summarize the scientific evidences and the potential implications of HCV pharmacogenomics in this rapidly evolving era of anti-HCV drug development.
\end{abstract}

Keywords: hepatitis $\mathrm{C}$ virus, pharmacogenomics, PEG-IFN/RBV, DAAs, Latin America

\section{Introduction}

The combination of pegylated IFN-alpha plus ribavirin (PEG-IFN/RBV) has been the standard of care for chronic hepatitis $\mathrm{C}$ virus (HCV) infection since late last century. The ultimate goal of this dual therapy is to eradicate HCV infection and thereby reduce the risk of progression to $\mathrm{HCV}$-related liver complications. The endpoint of $\mathrm{HCV}$ treatment is to achieve a sustained virologic response (SVR), which has been strongly associated with viral clearance and effectively a cure. ${ }^{1}$

In addition to its limited efficacy with the most prevalent HCV genotype worldwide, the PEG-IFN/RBV combination therapy frequently produces intolerability and substantial adverse effects. Consequently, the assessment of several viral (genotypes, viral load, mutations, etc.) and host (age, gender, degree of liver fibrosis, and alcohol consumption, etc.) factors were promptly incorporated in the treatment decision making in order to satisfy the urgent need of prediction of the PEG-IFN/RBV outcome. However, despite these influencing determinants, the existence of ethnic variability and individual differences observed in the clinical setting could not be thoroughly explained; strongly suggesting that host genetic factors might also play a significant role in $\mathrm{HCV}$ treatment response. ${ }^{1}$

In 2009-2010, several research groups confirmed the significant association of single-nucleotide polymorphisms (SNPs) at IFNL4 and ITPA genes with PEG-IFN/ RBV treatment outcome among $\mathrm{HCV}$-infected patients from around the world. ${ }^{2-7}$ This submit your manuscrip

Dovepress

f

in - 
breakthrough not only impacted the prognosis and treatment of HCV infection, but also allowed to identify patients with unfavorable alleles, in whom the response to PEG-IFN/RBV treatment would be poor, making them ideal candidates for emerging therapies.

Recently, the development of direct-acting antiviral agents (DAAs) represents an outstanding progress in the field of therapeutic options for HCV chronic infection, which have improved the chance of cure and ameliorated the prognosis of the disease. These new antiviral agents offer a range of advantages compared with their predecessors, have multigenotypic activity, shorter schemes, fewer side effects, and higher cure rates, including for those in advanced stages of infection. ${ }^{8,9}$ In this current scenario, pharmacogenetics seems to have a reduced usefulness. However, the universal availability of these new treatment regimens - with DAAs alone or in combination with other DAAs or PEG-IFN/RBV - is still not a reality, particularly for HCV patients in the public health system of Latin American countries. ${ }^{10-12}$

In this review, we summarize the scientific evidences and the potential implications of $\mathrm{HCV}$ pharmacogenomics in this rapidly evolving era of anti-HCV drug development.

\section{HCV in Latin America: burden of infection and accessibility to treatment}

The burden of HCV infection is expected to increase around the world and Latin America is no exception to this scenario. ${ }^{13}$

In recent years, different studies have addressed the epidemiology of chronic HCV infection in Latin America. ${ }^{14,15}$ Nonetheless, there is still a paucity of information in the region, since most of the available data come from spontaneous demand studies in specific groups, which do not faithfully represent the prevalence in the general population. ${ }^{16,17}$

Despite this limitation, it is estimated an average prevalence rate for $\mathrm{HCV}$ of $2.0 \% \pm 0.25 \%$ in the adult population, which represents at least 10 million individuals who are antiHCV positive in Latin America. ${ }^{14,17,18}$ On the whole, Latin America has the lowest HCV prevalence compared with others regions around the world. However, these rates vary among countries and even in different areas within the same country.

Most of the HCV-infected individuals in Latin America are in Brazil with more than 2.5 million cases, being among the 10 countries with more cases worldwide. ${ }^{17,19,20}$ The second largest epidemiologic burden due to $\mathrm{HCV}$ is found in Mexico with 1.6 million cases. The third and fourth place is held by Colombia and Argentina with $\sim 690,000$ and 342,000 cases, respectively. ${ }^{17,21,22}$
There is a consensus that most cases occur among people aged 55 years and older. ${ }^{23,24}$ Likewise, it was estimated that the peak incidence occurred in the mid to late 90 s and predicted a slow decline in the prevalence for the next decades as a result of prophylactic measures and the effectiveness of current antiviral agents. ${ }^{17,25}$ However, due to the fact that $75 \%$ of HCV infections evolve into chronicity, the consequences of the natural course of the disease are observed decades after the infection; resulting in future high costs of monitoring, hospitalization, or transplantation for health care systems. ${ }^{17,18,20}$

As regards $\mathrm{HCV}$ genotypes, in Latin America $>50 \%$ of the cases are caused by genotype 1 , followed by 2 or 3 depending on the country. ${ }^{26}$ This poses a drawback, because the overall cure rate of patients infected with genotype 1 treated with PEG-IFN- $\alpha / \mathrm{RBV}$ is low, being $40 \%-50 \%,{ }^{1}$ which represents high costs to governments without comparable effectiveness.

In addition, $<2 \%$ of $\mathrm{HCV}$ chronically infected individuals have access to treatment. ${ }^{18,24,25}$ Particularly, access to standard PEG-IFN/RBV therapy is extremely limited in underserved populations without affiliation to health care systems, which are paradoxically the neediest.

In recent years, several DAAs have been developed. These new antiviral agents represent a great hope for millions of chronically infected individuals because their use may lead to excellent cure rates. Nevertheless, the high cost of these new drugs is one of the major, although not the only, limiting factors for its broad implementation, mainly in low- or lower-middle income countries (Figure 1). ${ }^{10,11}$

In Latin America, the public health care systems often show fragmented schemes mostly concentrated on specific sectors of society. However, in many cases, macroeconomic troubles, political obstruction, and inadequate management led to pay-as-you-go in practice. Although HCV treatment-related costs are mostly responsibility of the public health system, in $50 \%$ of cases patients paid treatments from their own pocket, $25 \%$ were paid by private insurance, and only $25 \%$ treatments were afforded by the public health sector. Moreover, $>95 \%$ of patients infected with viral hepatitis belong to a low-income population and/or are uninsured, and they cannot afford to pay the current market prices of DAAs (Figure 1). ${ }^{27}$

In addition, viral hepatitis is not considered to be a severe health problem by health officials in Latin America, which in turn have manifested ignorance or reluctance toward a state program of detection or treatment of this disease. The lack of precise epidemiologic information about HCV infection is an ongoing difficulty, which translates into the lack of precision of who and how many people are infected and primary risk 


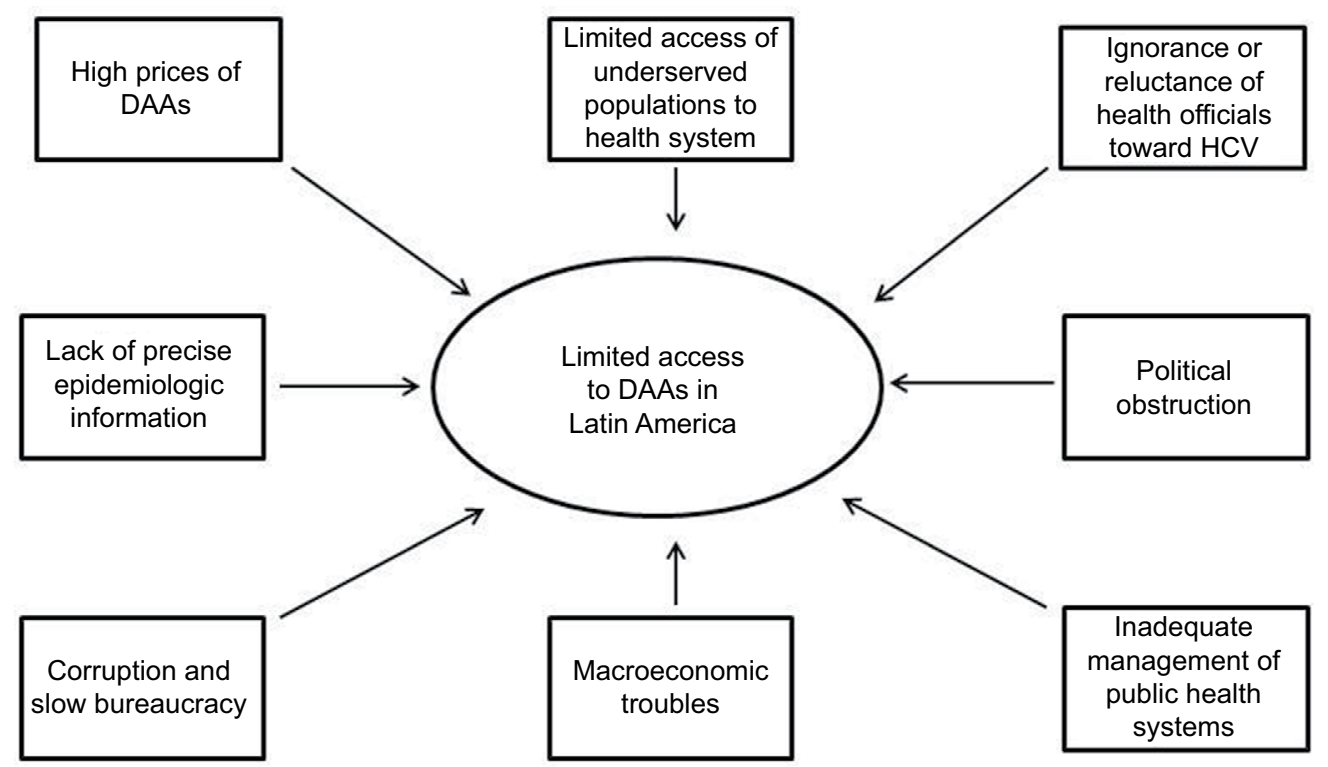

Figure I Limiting factors for the global access to DAAs in Latin America.

Abbreviations: DAAs, direct-acting antiviral agents; $\mathrm{HCV}$, hepatitis $\mathrm{C}$ virus.

factors involved. ${ }^{18}$ Another limiting factor is the corruption and slow bureaucracy to introduce these drugs; even though the pharmaceutical industry has declared a responsibility to create agreements based on the economy of each country for the marketing of the antiviral drugs (Figure 1). ${ }^{28}$

At present, the first-wave of NS3/NS4 inhibitors (telaprevir and boceprevir), are the most available DAAs in Latin America. ${ }^{28-30}$ However, these are no longer used due to their limitations compared with the second-generation inhibitors and those targeted against other $\mathrm{HCV}$ genes. ${ }^{31}$

Therefore, the strategy in the region is to use secondgeneration DAAs in those countries, where available, and delay patient treatment until arrival in those countries, where they are not. ${ }^{28}$

In recent years, simeprevir, daclatasvir, and sofosbuvir have been or are being approved and are currently available in Argentina and Brazil. ${ }^{12,28,30}$ At the moment, the prescription is restricted to older patients with unequivocal signs of liver damage.

In 2014, Gilead announced a voluntary license agreement with several Indian drug manufacturers that allow these companies to produce and sell generic versions of sofosbuvir and ledipasvir. Bolivia is the only country in the region benefited from this measure.

In order to secure some price discounts on these highcost treatments The Union of South American Nations has proposed the creation of a fund to negotiate centralized purchases of the HCV treatments and began the process of joint purchase of DAAs through the Pan American Health Organization Strategic Fund last year.

\section{HCV pharmacogenomics}

In 2009, four independent genome-wide association studies (GWAS) reached the same and definitive conclusion: polymorphisms rs $12979860 \mathrm{C} / \mathrm{T}$ and $\mathrm{rs} 8099917 \mathrm{G} / \mathrm{T}$ in or near the IL28B gene, also known as IFN lambda 3 (IFN- $\lambda 3$ or IFNL3) but as the discovery of IFNL4 is now classified as an IFNL4 SNP, significantly affect the spontaneous clearance of acute $\mathrm{HCV}$ infection and the response to PEG-IFN/RBV therapy (Table 1). ${ }^{2-5}$ The two GWAS-identified SNPs, rs12979860 and rs8099917 are in low to strong linkage disequilibrium, based on specific populations tested, and both markers were used for predicting response to PEG-IFN and RBV therapy. ${ }^{4,32}$

Prokunina-Olsson et al identified a transiently induced region in a new gene member, denoted IFNL4 gene, which shows a dinucleotide variant (rs368234815 or ss469415590 $\mathrm{TT} / \Delta \mathrm{G})$. This novel interferon is produced only in carriers of $\Delta \mathrm{G}$ allele carriers and has been related to unsuccessful viral clearance in the presence or absence of treatment (Table 1). ${ }^{33}$ IFNL4 variants rs368234815 and rs12979860 are in high linkage disequilibrium and provide similar predictive information in Asians, and comparable information in Europeans. However, in individuals of African ancestry there is a lower linkage disequilibrium between these markers and rs368234815 is significantly more informative than rs12979860. ${ }^{33-35}$

Since then, various studies have verified the impact of IFNL4 on HCV infection and treatment outcome across different HCV genotypes, ${ }^{32,36,37}$ and in individuals coinfected with HIV. ${ }^{38}$ Although on-treatment predictors are more significantly associated with therapeutic success, ${ }^{39}$ the viral genotype and the rs368234815 IFNL4 SNP are considered 
Table I Genetic factors related to HCV pharmacogenomics

\begin{tabular}{|c|c|c|c|c|}
\hline NCBI dbSNP id & Location & Alleles & Associated with & References \\
\hline \multirow[t]{2}{*}{ rs3682348I5 } & IFNL4 & $\mathrm{TT}$ & Spontaneous and/or PEG-IFN/RBV treatment-induced HCV clearance & $33-35,40,43$ \\
\hline & & $\Delta \mathrm{G}$ & HCV persistence and/or PEG-IFN/RBV treatment failure & \\
\hline \multirow[t]{2}{*}{ rs I 2979860} & IFNL4 & C & Spontaneous and/or PEG-IFN/RBV treatment-induced HCV clearance & $2-5,32,35-42$ \\
\hline & & $\mathrm{T}$ & HCV persistence and/or PEG-IFN/RBV treatment failure & \\
\hline \multirow[t]{2}{*}{ rs8099917 } & IFNL4 & $\mathrm{T}$ & Spontaneous and/or PEG-IFN/RBV treatment-induced HCV clearance & $2-5,32$ \\
\hline & & G & HCV persistence and/or PEG-IFN/RBV treatment failure & \\
\hline \multirow[t]{2}{*}{ rs II 27354} & ITPA & A & Low risk of RBV-induced hemolytic anemia & $47-52$ \\
\hline & & $\mathrm{C}$ & High risk of RBV-induced hemolytic anemia & \\
\hline \multirow[t]{2}{*}{ rs7270I0I } & ITPA & C & Low risk of RBV-induced hemolytic anemia & $47-52$ \\
\hline & & A & High risk of RBV-induced hemolytic anemia & \\
\hline
\end{tabular}

Abbreviations: $\mathrm{HCV}$, hepatitis C virus; PEG-IFN/RBV, pegylated IFN-alpha plus ribavirin; SNP, single-nucleotide polymorphism.

the most powerful pretreatment predictors of response to PEG-IFN/RBV therapy. ${ }^{40}$

For treatment-naïve patients with genotype 1 infection who are treated with protease inhibitor combinations, IFNL4 genotypes predicts response and also eligible for the shorter durations of therapy. ${ }^{41}$ Although all IFNL4 genotypes have improved response rates as compared with patients treated with PEG-IFN/RBV only, patients with the favorable IFNL4 genotype still have higher response rates with the protease inhibitor combination in treatment-naïve patients, and these response rates may guide patients and clinicians in their treatment decisions.

Second-wave DAAs, such as sofosbuvir, simeprevir, and daclatasvir, can be administered in combination with PEG-IFN/RBV as triple therapy for patients with HCV genotype 1 . In these highly potent regimens, cirrhosis and IFNL4 genotype are still predictors of response. ${ }^{42,43}$ In contrast, although host genetic factors have a lesser impact on treatment response in IFN- and RBV-free regimens, recent studies have reported that the IFNL4 variants can influence the risk of antiviral resistance. ${ }^{44-46}$

In addition, recent reports have demonstrated that polymorphisms at other genes could also be related to the risk of PEG-IFN/RBV treatment withdrawal due to drug-related adverse effects. ${ }^{47-49}$ In this regard, one of the most important treatment-limiting toxicities is RBV-induced hemolytic anemia, which has been linked to two functional polymorphisms in the ITPA gene - a missense variant in exon 2 (rs1127354) and a splice-altering SNP in intron 2 (rs7270101) - and to a nonfunctional one (rs6051702). ${ }^{47,48}$ These variants induce an inosine triphosphate pyrophosphohydrolase deficiency, a benign red cell enzymopathy associated with a protective effect against RBV-induced hemolytic anemia in HCVinfected patients. ${ }^{47-50}$

It is important to highlight that ITPA gene polymorphisms are not related to treatment response but to the prediction of
RBV-induced hemolytic anemia and thus, the need of dosereduction or even treatment withdrawal (Table 1). ${ }^{49,51}$

Although new therapies with first-wave protease inhibitors improved SVR, they also increased side effects, such as rash and anemia. Several studies highlighted the ITPA role in predicting anemia in these new regimens. ${ }^{50,52}$ In the case of second-wave protease (such as simeprevir) and polymerase inhibitors (such as sofosbuvir), effectiveness have been further increased and adverse effects have been considerably reduced. Most of these regimens are RBV-free and they are already approved or undergoing phases II and III studies in different countries. ${ }^{42}$

\section{Genetic ancestry influences HCV pharmacogenomics in Latin America}

Along the end of the Pleistocene (11,700 years ago), a limited number of immigrants arrived to the American continent entering from the eastern edge of Siberia by crossing the Bering Strait. Immigrants explored the territories, some settled, others keep moving south and eastward within the American continent. After a long period of isolation, the continent was explored by Europeans conquerors who - after submitting the aboriginals - started the colonization process. The major transatlantic migratory contribution to Latin America was provided by the Iberians who colonized the major extension of the continent. During the late sixteenth and beginning of the seventeenth century, European colonists introduced West and East Sub-Saharan Africans as working forces. Throughout the Americas, even within the same country, historical differences in pattern of settlement and migration have resulted in a wide range of genetic variation reflecting complex admixed events involving actors of different ancestral background. ${ }^{53}$

Regarding the maternal lineage, in general, it can be observed a high proportion of Native American maternal ancestry, belonging to haplogroups $\mathrm{A}-\mathrm{D}$ of the mitochondrial 
DNA. Certainly, the different proportion found in each country will depend on its own colonization history. ${ }^{54-58}$

In contrast, the paternal lineage depicts a different scenario. In this case, the European contribution is mainly represented by the R1b haplogroup in the Y-chromosome. ${ }^{55,59}$ The proportion of the Native American haplogroup Q1a3a, depends on the survival of the Native American males, given their killing carried out by Europeans during the conquest.

Although both male and maternal lineages offer an idea of the different parental populations contributions, autosomal ancestry-informative markers quantify the genetic admixture extent. ${ }^{55}$ In general, urban towns of Argentina, Mexico, Chile, Colombia, Uruguay, and South of Brazil showed that $>55 \%$ of the global ancestry belongs to European contribution followed by Native American and $<10 \%$ of African contribution. ${ }^{55,60,61}$ Instead, rural Mexico and urban populations in Peru and Bolivia showed the major contribution of Native American ancestry in part due to the high population density of aboriginal in the region at the moment of the conquest. ${ }^{60-63}$

Latin America experienced one of the largest admixture processes in a reduced span of time of just 20 generations. These circumstances have important implications for the expected relative proportion of ancestral genetic makeup with potential effects on disease susceptibilities, ability to metabolize therapeutic compounds demonstrating the need to genetic ancestry determination in future genetic association studies.

Several epidemiologic studies have demonstrated that the allele frequencies of IFNL4 and ITPA predictive SNPs exhibit variations among worldwide populations with different ancestry background. ${ }^{32,64}$ However, these data obtained from well-defined ethnic groups cannot be extrapolated to genetically admixed and multiethnic populations, such as those in Latin America. ${ }^{65}$

Several research groups have confirmed the significant association of IFNL4 and ITPA SNPs with PEG-IFN/RBV treatment outcome among $\mathrm{HCV}$-infected Latin American patients. ${ }^{66-72}$ Meanwhile, in the general population of the region, these predictive polymorphisms exhibit extremely variable frequencies. ${ }^{73,74}$ Nevertheless, in order to avoid drawing false conclusions, it is important to highlight that the high heterogeneity of Latin American populations was not taken into consideration by these groups and, therefore, the analysis of genetic ancestry was not carried out in these studies. ${ }^{65}$

The population diversity in Latin American, with trihybrid ancestral roots and five centuries of admixture, cannot be detected by color/race self-identification and should be described by molecular approaches. In this regard, recent studies have concluded that the distribution of these SNPs is closely related to the genetic ancestry in Latin America. ${ }^{35,75-78}$ A study carried out among 2150 non$\mathrm{HCV}$-infected individuals from Argentina, Peru, Bolivia, and Paraguay, showed that the frequency of IFNL4 and ITPA SNPs exhibits a specific geographical pattern of distribution, even within the same country (Figures 2-4), and is closely related to the maternal and paternal ancestry of the population (Figures 5 and 6). In fact, the prevalence of favorable genotypes is significantly higher in populations with European ethnicity, intermediate in admixed individuals, and the lowest in populations with Native American ancestry background. ${ }^{75,76}$ These findings were confirmed in western Mexico, where the $\mathrm{TT} / \mathrm{GG} / \Delta \mathrm{G}$ risk haplotype in the IFNL4 gene predominates in Native Americans when compared with the "Mestizos" (admixed) group. ${ }^{35}$ With respect to the association of these SNPs with HCV clearance in the presence or absence of PEG-IFN/RBV treatment, the protective alleles were more frequently observed among admixed Mexicans with spontaneous clearance of $\mathrm{HCV}$ infection. ${ }^{35}$ Moreover, studies carried out among HCV chronic patients from Brazil revealed that IFNL4 polymorphisms predict therapy response in patients with admixed ancestry. ${ }^{77,78}$ Interestingly, this association is influenced by ancestry; being the African genetic contribution higher among the nonresponder patients with the rs12979860 TT genotype, whereas the Native American and European genetic ancestry prevail in the SVR group. ${ }^{77}$

\section{Implications in the era of DAAs}

Several studies carried out in different geographical scenarios have shown that DAAs implementation is cost-effectiveness per person treated, but pent-up demand for treatment will create challenges for financing. ${ }^{10,79,80}$ Cost-effectiveness studies have not been conducted in Latin America and, therefore, the implication that these new therapies might have in healthrelated economics is unpredictable and its relevance in $\mathrm{HCV}$ control will probably remain negligible as long as access to the therapy cannot be expanded. ${ }^{81}$

In this region, the high rate of infections with HCV genotype 1 and the high frequency in Native American populations of the TT genotype of IFNL4 SNP rs12979860 - markers associated with poor response to PEG-IFN/RBV therapy in both cases ${ }^{35,75-78}$ - support the hypothesis that the implementation of IFN-free regimen should be beneficial in terms of cost-benefit. However, before or until global availability to DAAs is achieved, the identification of host predictive markers of antiviral therapy outcome could still be useful, as it will help prioritize DAA access. 


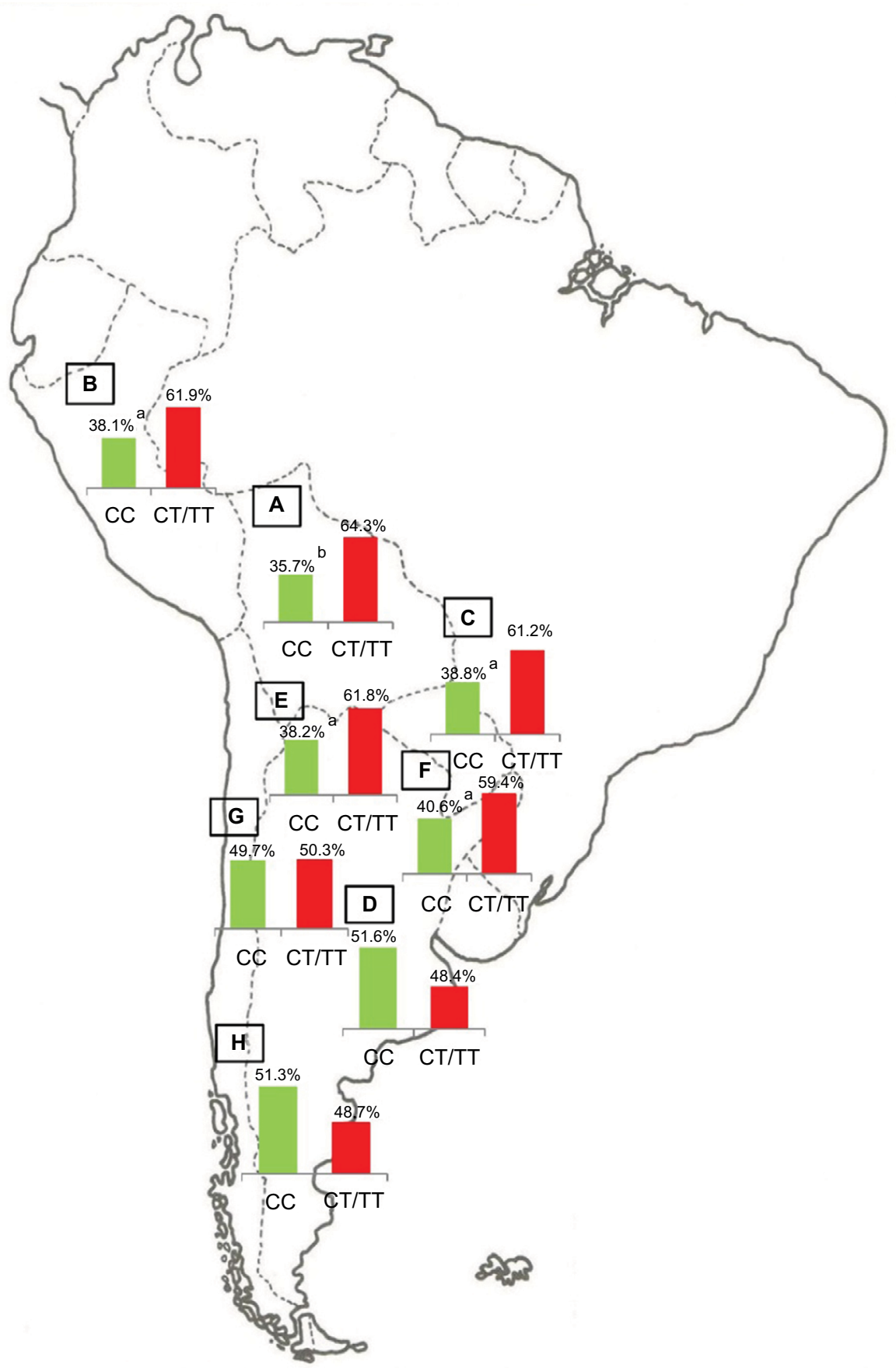

Figure 2 IFNL4 SNP rs 12979860

Notes: Prevalence of the favorable (CC) and risk (CT/TT) genotypes of IFNL4 SNP rs 12979860 in Bolivia (A, $n=185)$, Peru (B, $n=76)$, Paraguay (C, $n=98)$, and the different geographic regions of Argentina: Central ( $\mathbf{D}, n=991)$, Northwestern $(\mathbf{E}, n=250)$, Northeastern $(\mathbf{F}, n=260)$, Western $(\mathbf{G}, n=175)$, and Southern $(\mathbf{H}, n=115)$ areas. ${ }^{2} p<0.05$ when comparing samples from the Central region of Argentina with those from the Northeastern and Northwestern regions, Peruvians and Paraguayans; ${ }^{b} p<0.000 \mathrm{I}$ when comparing samples from the Central region of Argentina with Bolivians. Copyright @2014. Nature Publishing Group. Adapted from Trinks J, Hulaniuk ML, Caputo M, et al. Distribution of genetic polymorphisms associated with hepatitis $C$ virus $(\mathrm{HCV})$ antiviral response in a multiethnic and admixed population. Pharmacogenomics J. 2014;14(6):549-554.75 Adapted with permission from Trinks J, Hulaniuk ML, Caputo M, et al. Distribución de polimorfismos de nucleótido simple (SNPs) predictores de la respuesta al tratamiento antiviral en la infección crónica por el virus de la hepatitis $\mathrm{C}(\mathrm{HCV})$ en las distintas regiones geográficas de Argentina [Distribution of singlenucleotide polymorphisms (SNPs) predictive of antiviral treatment response in hepatitis C virus (HCV) chronic infection in different geographic regions in Argentina]. Medicina (B Aires). 2014;74 (Suppl 3):SI 17-SI 18. Spanish. ${ }^{76}$ Abbreviation: SNP, single-nucleotide polymorphism.

Furthermore, it is important to highlight that IFNL4 not only plays an important role on establishing the likelihood of treatment response with PEG-IFN/RBV and to triple (single DAA plus PEG-IFN/RBV) and quadruple (two DAAs plus PEG-IFN/
RBV) regimens, ${ }^{41,42}$ but also exert, an effect on the early viral kinetics in $\mathrm{HCV}$ chronic patients receiving the emerging IFN and RBV-free schemes. ${ }^{82,83}$ In addition, recent studies have reported that the presence of resistance variants, number, and 


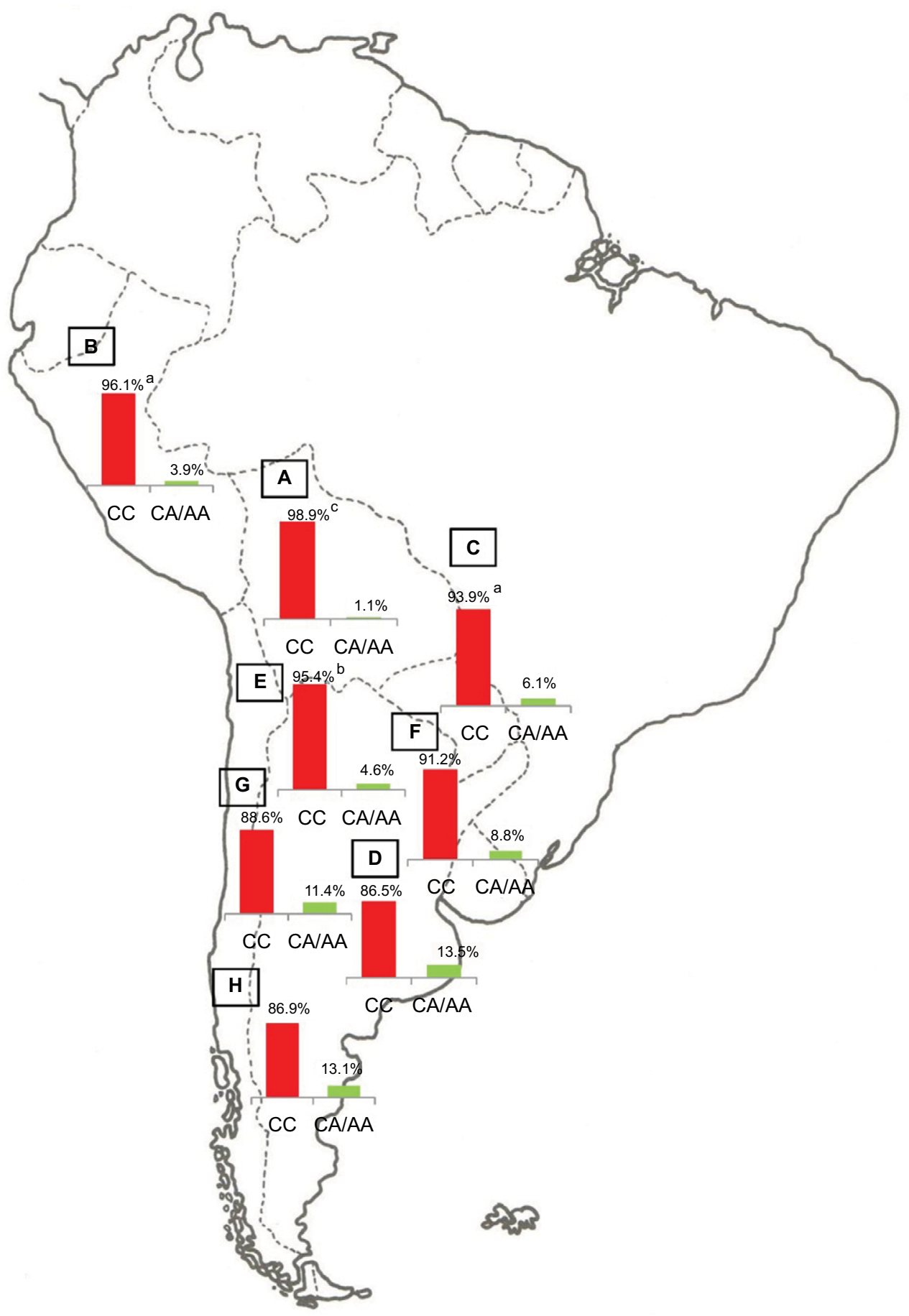

Figure 3 ITPA SNP rs I I 27354.

Notes: Prevalence of the favorable (CA/AA) and risk (CC) genotypes of ITPA SNP rs I 27354 in Bolivia (A, $n=185)$, Peru (B, $n=76)$, Paraguay (C, $n=98)$, and the different geographic regions of Argentina: Central (D, $n=991)$, Northwestern $(\mathbf{E}, n=250)$, Northeastern $(\mathbf{F}, n=260)$, Western $(\mathbf{G}, n=175)$, and Southern $(\mathbf{H}, n=115)$ areas. ${ }^{2} p<0.05$ when comparing samples from the Central region of Argentina with Peruvians and Paraguayans; ${ }^{b} p<0.00$ I when comparing samples from the Central region of Argentina with those from the Northwestern region; ${ }^{c} p<0.0001$ when comparing samples from the Central region of Argentina with Bolivians. Copyright $\odot 2014$. Nature Publishing Group. Adapted from Trinks J, Hulaniuk ML, Caputo M, et al. Distribution of genetic polymorphisms associated with hepatitis $\mathrm{C}$ virus (HCV) antiviral response in a multiethnic and admixed population. Pharmacogenomics J. 2014;14(6):549-554.75 Adapted with permission from Trinks J, Hulaniuk ML, Caputo M, et al. Distribución de polimorfismos de nucleótido simple (SNPs) predictores de la respuesta al tratamiento antiviral en la infección crónica por el virus de la hepatitis C (HCV) en las distintas regiones geográficas de Argentina [Distribution of singlenucleotide polymorphisms (SNPs) predictive of antiviral treatment response in hepatitis C virus (HCV) chronic infection in different geographic regions in Argentina]. Medicina (B Aires). 2014;74 (Suppl 3):SI 17-SI 18. Spanish. ${ }^{76}$

Abbreviations: ITPA, inosine triphosphatase; SNP, single-nucleotide polymorphism. 


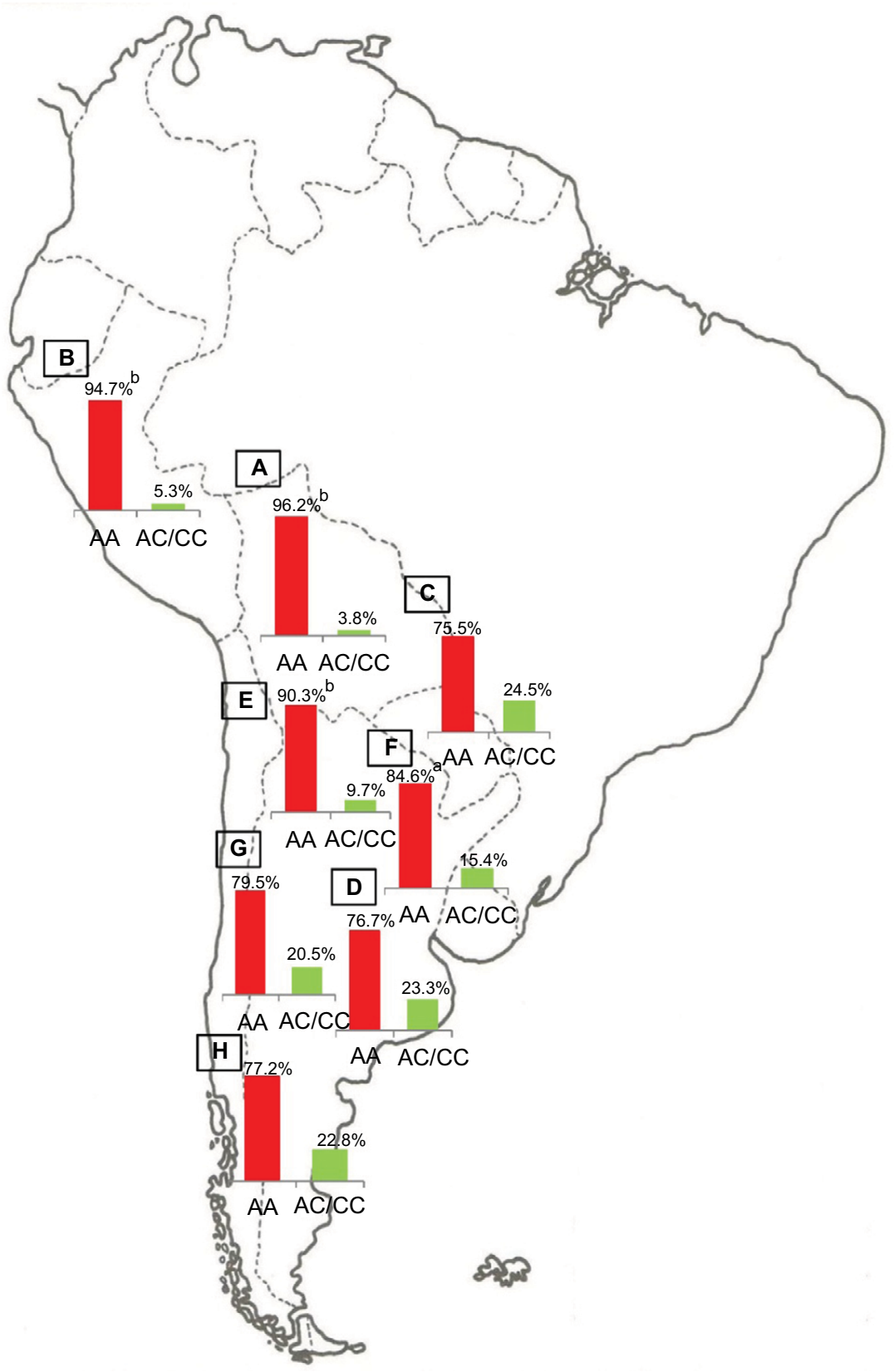

Figure 4 ITPA SNP rs7270101.

Notes: Prevalence of the favorable (AC/CC) and risk (AA) genotypes of ITPA SNP rs7270101 in Bolivia (A, $n=185)$, Peru (B, $n=76)$, Paraguay (C, $n=98)$, and the different geographic regions of Argentina: Central $(\mathbf{D}, n=991)$, Northwestern $(\mathbf{E}, \mathrm{n}=250)$, Northeastern $(\mathbf{F}, \mathrm{n}=260)$, Western $(\mathbf{G}, \mathrm{n}=175)$, and Southern $(\mathbf{H}, \mathrm{n}=115)$ areas. ${ }^{2} p<0.05$ when comparing samples from the Central region of Argentina with those from the Northeastern region; ${ }^{b} p<0.000$ I when comparing samples from the Central region of Argentina with those from the Northwestern region, Bolivians, and Peruvians. Copyright $\odot 2014$. Nature Publishing Group. Adapted from Trinks J, Hulaniuk ML, Caputo M, et al. Distribution of genetic polymorphisms associated with hepatitis $\mathrm{C}$ virus $(\mathrm{HCV})$ antiviral response in a multiethnic and admixed population. Pharmacogenomics J. 2014;14(6):549-554.75 Adapted with permission from Trinks J, Hulaniuk ML, Caputo M, et al. Distribución de polimorfismos de nucleótido simple (SNPs) predictores de la respuesta al tratamiento antiviral en la infección crónica por el virus de la hepatitis $\mathrm{C}(\mathrm{HCV})$ en las distintas regiones geográficas de Argentina [Distribution of singlenucleotide polymorphisms (SNPs) predictive of antiviral treatment response in hepatitis C virus (HCV) chronic infection in different geographic regions in Argentina]. Medicina (B Aires). 2014;74 (Suppl 3):SII7-SII8. Spanish. ${ }^{76}$

Abbreviations: ITPA, inosine triphosphatase; SNP, single-nucleotide polymorphism.

diversity of NS5A quasispecies is strongly associated with favorable IFNL4 genotypes, probably as a consequence of the fact that patients with the beneficial genotypes induce a more efficient antiviral response that results either in viral clearance or selection for viral adaptations. This regulating influence of host genetic factors on the nature of the viral quasispecies could be of clinical interest for consideration of IFN-free treatment options for patients with known IFNL4 status. ${ }^{44} 46$

In Latin America, pharmacogenomics could still provide an instrument to optimize $\mathrm{HCV}$ management, taking into account ethnic differences and explaining the variability in treatment response. As a consequence, $\mathrm{HCV}$ pharmacogenetics will still 


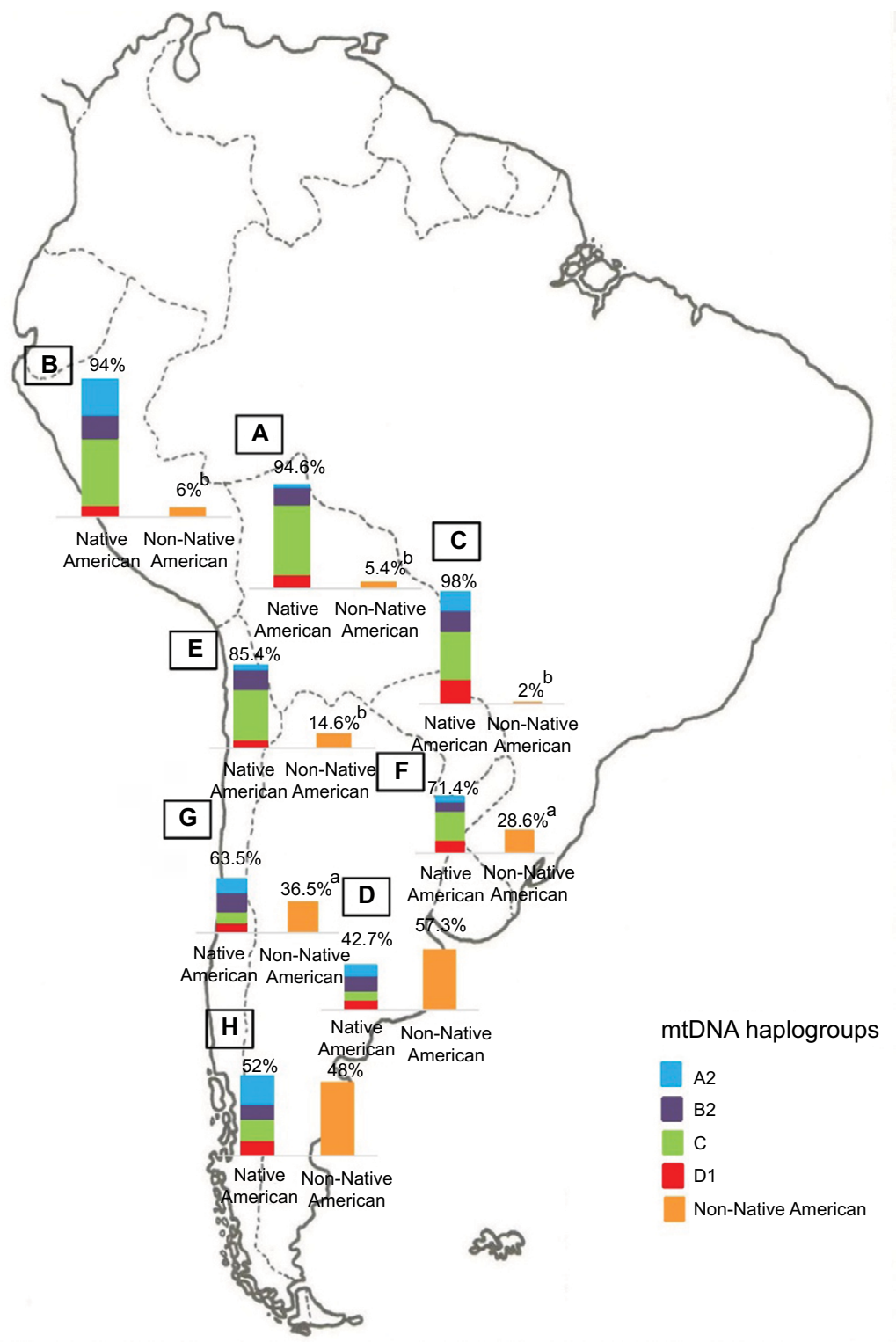

Figure 5 Maternal ancestry.

Notes: Prevalence of the Native American and non-Native American mtDNA haplogroups in Bolivia $(\mathbf{A}, \mathrm{n}=185)$, Peru (B, $\mathrm{n}=76)$, Paraguay (C, $\mathrm{n}=98)$, and the different geographic regions of Argentina: Central $(\mathbf{D}, n=991)$, Northwestern $(\mathbf{E}, \mathrm{n}=250)$, Northeastern $(\mathbf{F}, \mathrm{n}=260)$, Western $(\mathbf{G}, \mathrm{n}=175)$, and Southern $(\mathbf{H}, \mathrm{n}=115)$ areas. ${ }^{2} p<0.005$ when comparing samples from the Central region of Argentina with those from the Western and Northeastern regions; ${ }^{b} p<0.000$ I when comparing samples from the Central region of Argentina with those from the Northwestern region, Bolivia, Peru, and Paraguay. Copyright @2014. Nature Publishing Group. Adapted from Trinks J, Hulaniuk ML, Caputo M, et al. Distribution of genetic polymorphisms associated with hepatitis C virus (HCV) antiviral response in a multiethnic and admixed population. Pharmacogenomics J. 20 14; 14(6):549-554..$^{75}$ Adapted with permission from Trinks J, Hulaniuk ML, Caputo M, et al. Distribución de polimorfismos de nucleótido simple (SNPs) predictores de la respuesta al tratamiento antiviral en la infección crónica por el virus de la hepatitis $\mathrm{C}(\mathrm{HCV})$ en las distintas regiones geográficas de Argentina [Distribution of singlenucleotide polymorphisms (SNPs) predictive of antiviral treatment response in hepatitis $\mathrm{C}$ virus (HCV) chronic infection in different geographic regions in Argentina] Medicina (B Aires). 2014;74 (Suppl 3):SII7-SII8. Spanish. ${ }^{76}$

Abbreviation: $\mathrm{mtDNA}$, mitochondrial DNA.

represent an ongoing challenge for Latin American clinicians and hepatologists in the treatment decision making.

\section{Conclusion}

In the last 5 years, resonant advances related to infection by hepatitis $\mathrm{C}$ have been obtained, making conceivable that $\mathrm{HCV}$ chronic infection will soon become an easier-to-treat disease.

Nowadays, HCV treatment varies throughout the world because some regions have access to the new DAAs, whereas other areas have access only to PEG-IFN/RBV. Although the high prevalence of HCV genotype 1 in Latin America and unfavorable predictive SNPs among Native Americans highlight the need to implement new treatment regimens in these populations, the universal accessibility to DAAs is still not a reality in the region. Therefore, the PEG-IFN/ RBV treatment will still be the only therapy available until the costs of the new drugs have decreased and their access to $\mathrm{HCV}$ patients has globalized. 


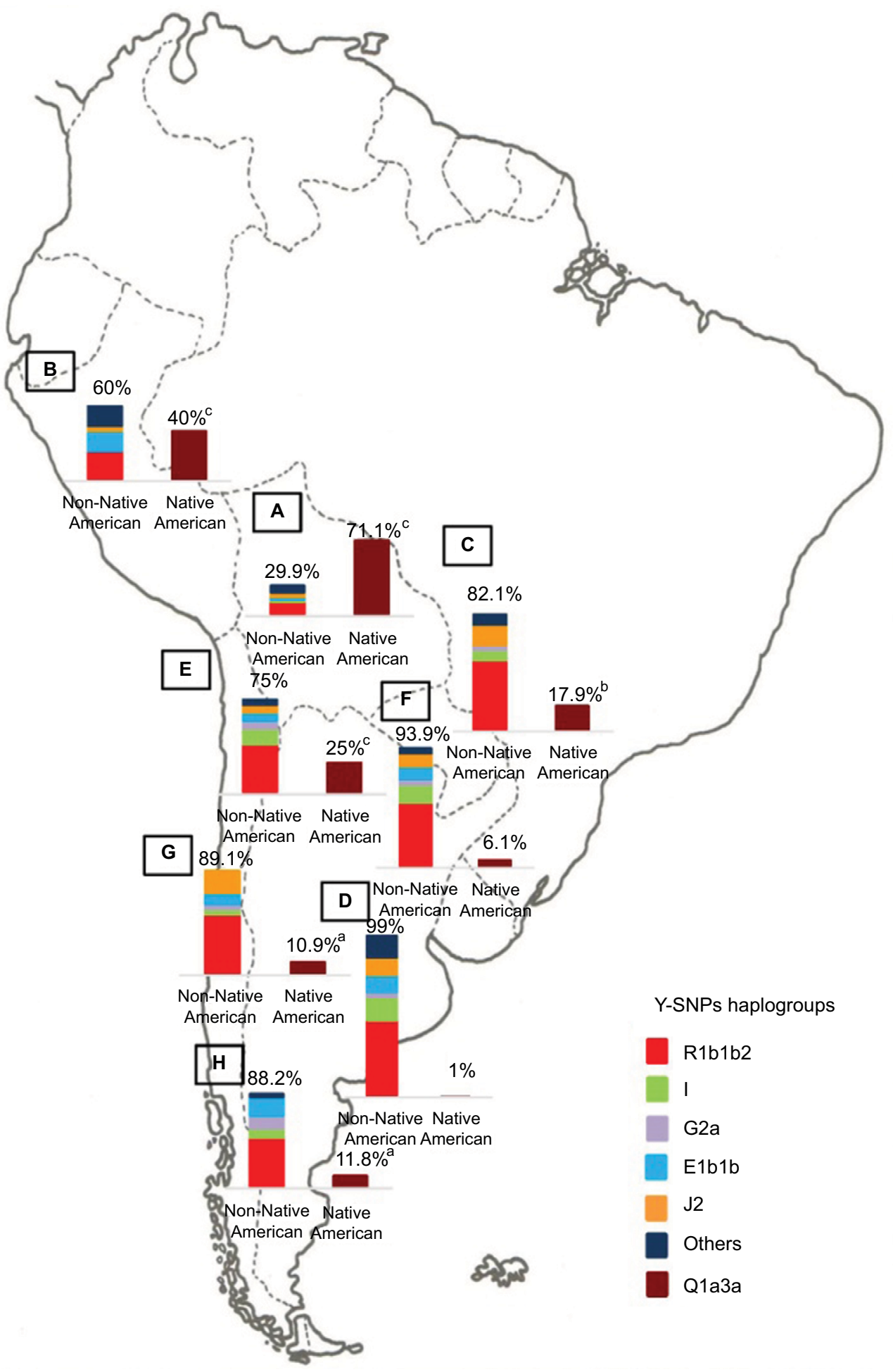

Figure 6 Paternal ancestry.

Notes: Prevalence of the Native American and non-Native American Y-SNPs haplogroups in Bolivia (A, $n=185)$, Peru (B, $n=76)$, Paraguay (C, $n=98)$, and the different

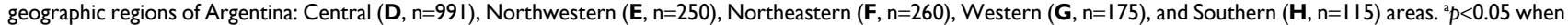
comparing samples from the Central region of Argentina with those from the Southern and Western regions; ${ }^{b} p<0.01$ when comparing samples from the Central region of Argentina with those from Paraguay; and ${ }^{c} p<0.0001$ when comparing samples from the Central region of Argentina with those from the Northwestern region, Bolivia, and Peru. Copyright @2014. Nature Publishing Group. Adapted from Trinks J, Hulaniuk ML, Caputo M, et al. Distribution of genetic polymorphisms associated with hepatitis $\mathrm{C}$ virus (HCV) antiviral response in a multiethnic and admixed population. Pharmacogenomics J. 2014;14(6):549-554. ${ }^{75}$ Adapted with permission from Trinks J, Hulaniuk ML, Caputo M, et al. Distribución de polimorfismos de nucleótido simple (SNPs) predictores de la respuesta al tratamiento antiviral en la infección crónica por el virus de la hepatitis $\mathrm{C}(\mathrm{HCV})$ en las distintas regiones geográficas de Argentina [Distribution of singlenucleotide polymorphisms (SNPs) predictive of antiviral treatment response in hepatitis C virus (HCV) chronic infection in different geographic regions in Argentina]. Medicina (B Aires). 2014;74 (Suppl 3):SI 17-SI 18. Spanish. ${ }^{76}$

Abbreviation: Y-SNPs, Y-chromosome single-nucleotide polymorphisms. 
In this review, the report of several studies concerning pharmacogenetic factors related to $\mathrm{HCV}$ treatment in Latin America might help to adjust the regional treatment policies for HCV infection based on greater certainty in studies with populations with such genetic characteristics. They also confirm that, in this vast territory, there are populations with different genotypic characteristics that might, depending on the situation, require different approaches to treatment and research.

In this perspective, the assessment of host genetic markers in all $\mathrm{HCV}$ patients to predict response and evaluate the risk-benefit of available therapies might be useful to improve strategies and fight the infection and could be a cost-effective means of risk stratification in the developing countries. In this regard, several scientific societies and studies have declared that, until global access to DAAs is guaranteed, treatment-naïve patients exhibiting favorable clinical, genetic, and virologic profiles could still benefit with the PEG-IFN/RBV regimen; thus restricting the use of newer and expensive treatment schemes for "difficult to treat" patients. ${ }^{22,29,41,70,84-87}$

In future decades, it is expected that, particularly in the developing countries, the burden of HCV disease increases due to the absence of an effective vaccine, the insufficient amount of public awareness, and preventive measures..$^{13,14,17}$ Therefore, regardless of the great therapeutic advances, improvements in HCV surveillance, epidemiologic mapping, testing, prevention, and therapy are urgently needed. The challenge now is to overcome barriers to HCV testing and improve access to antiviral treatment in the low- and middle-income countries. Guarantee access to medicines is a joint responsibility of governments, multilateral agencies, and nongovernmental organizations. But also, pharmaceutical companies should be a part of the solution. Eventually, the global HCV control will be achieved with the joint efforts of governments, researchers, and public health workers.

\section{Acknowledgments}

This review was partly supported by grants from "Research Council of the Italian Hospital of Buenos Aires", "Instituto Universitario del Hospital Italiano de Buenos Aires", and PICT 2014-1675.

\section{Disclosure}

The authors report no conflicts of interest in this work.

\section{References}

1. Conteduca V, Sansonno D, Russi S, Pavone F, Dammacco F. Therapy of chronic hepatitis $\mathrm{C}$ virus infection in the era of direct-acting and host-targeting antiviral agents. J Infect. 2014;68(1):1-20.
2. Suppiah V, Moldovan M, Ahlenstiel G, et al. Interleukin 28B is associated with response to Hepatitis $\mathrm{C}$ interferon-alpha and ribavirin therapy. Nat Genet. 2009;41(1):1100-1104.

3. Tanaka Y, Nishida N, Sugiyama M, et al. Genome-wide association of Interleukin $28 \mathrm{~B}$ with response to interferon alpha and ribavirin therapy for chronic hepatitis C. Nat Genet. 2009;41(10):1105-1109.

4. Ge D, Fellay J, Thompson AJ, et al. Genetic variation in interleukin 28B predicts hepatitis C treatment-induced viral clearance. Nature. 2009;461(7262):399-401.

5. Rauch A, Kutalik Z, Descombes P, et al. Genetic variation in interleukin $28 \mathrm{~B}$ is associated with chronic hepatitis $\mathrm{C}$ and treatment failure: genomewide association study. Gastroenterology. 2010;138(4):1338-1345.

6. Fellay J, Thompson AJ, Ge D, et al. ITPA gene variants protect against anemia in patients treated for chronic hepatitis C. Nature. 2010;464(7287):405-408.

7. Sakamoto N, Tanaka Y, Nakagawa M, et al. ITPA gene variant protects against anemia induced by pegylated interferon- $\alpha$ and ribavirin therapy for Japanese patients with chronic hepatitis C. Hepatol Res. 2010;40(11):1063-1071.

8. Barritt AS 4th, Fried MW. Maximizing opportunities and avoiding mistakes in triple therapy for hepatitis C virus. Gastroenterology. 2012;142(6):1314-1323.

9. Sadler MD, Lee SS. Revolution in hepatitis C antiviral therapy. Br Med Bull. 2015;113(1):31-44.

10. Rein DB, Wittenborn JS, Smith BD, Liffmann DK, Ward JW. The cost-effectiveness, health benefits, and financial costs of new antiviral treatments for hepatitis C virus. Clin Infect Dis. 2015;61(2):157-168.

11. Silva-Vidal KV, Méndez-Sánchez N. The good, the bad and the ugly of the new treatments for hepatitis C virus. Ann Hepatol. 2014;13(5):574-575.

12. Olmedo DB, Cader SA, Porto LC. IFN- $\lambda$ gene polymorphisms as predictive factors in chronic hepatitis $\mathrm{C}$ treatment-naive patients without access to protease inhibitors. J Med Virol. 2015;87(10):1702-1715.

13. Cooke GS, Lemoine M, Thursz M, et al. Viral hepatitis and the Global Burden of Disease: a need to regroup. J Viral Hepat. 2013;20(9): 600-601.

14. Szabo SM, Bibby M, Yuan Y, et al. The epidemiologic burden of hepatitis C virus infection in Latin America. Ann Hepatol. 2012;11(5):623-635.

15. Alvarado-Mora MV, Pinho JR. Epidemiological update of hepatitis B, C and delta in Latin America. Antivir Ther. 2013;18(3 Pt B):429-433.

16. Flichman DM, Blejer JL, Livellara BI, et al. Prevalence and trends of markers of hepatitis B virus, hepatitis $\mathrm{C}$ virus and human Immunodeficiency virus in Argentine blood donors. BMC Infect Dis. 2014;14:218.

17. Kershenobich D, Razavi HA, Sánchez-Avila JF, et al. Trends and projections of hepatitis $\mathrm{C}$ virus epidemiology in Latin America. Liver Int. 2011;31 (Suppl 2):18-29.

18. Panduro A, Roman S. Need of righteous attitudes towards eradication of hepatitis C virus infection in Latin America. World J Gastroenterol. 2016;22(22):5137-5142.

19. Pereira LM, Martelli CM, Moreira RC, et al. Prevalence and risk factors of Hepatitis C virus infection in Brazil, 2005 through 2009: a crosssectional study. BMC Infect Dis. 2013;13:60.

20. Ferreira PR, Brandão-Mello CE, Estes C, et al. Disease burden of chronic hepatitis C in Brazil. Braz J Infect Dis. 2015;19(4):363-368.

21. Ridruejo E, Bessone F, Daruich JR, et al. Hepatitis C virus infection in Argentina: burden of chronic disease. World J Hepatol. 2016;8(15): 649-658.

22. Lozano-Sepulveda S, Bryan-Marrugo O, Merino-Mascorro J, Rivas-Estilla AM. Approachability to the new anti-HCV direct acting antiviral agents in the Latin American context. Future Virol. 2016;11(1):39-46.

23. Bruggmann P, Berg T, Øvrehus AL, et al. Historical epidemiology of hepatitis C virus (HCV) in selected countries. J Viral Hepat. 2014;21 (Suppl 1):5-33.

24. Razavi H, Waked I, Sarrazin C, et al. The present and future disease burden of hepatitis $\mathrm{C}$ virus (HCV) infection with today's treatment paradigm. J Viral Hepat. 2014;21 (Suppl 1):34-59.

25. Hatzakis A, Chulanov V, Gadano AC, et al. The present and future disease burden of hepatitis $\mathrm{C}$ virus ( $\mathrm{HCV}$ ) infections with today's treatment paradigm - volume 2. J Viral Hepat. 2015;22 (Suppl 1):26-45. 
26. Messina JP, Humphreys I, Flaxman A, et al. Global distribution and prevalence of hepatitis C virus genotypes. Hepatology. 2015;61(1):77-87.

27. Suthar AB, Harries AD. A public health approach to hepatitis $\mathrm{C}$ control in low- and middle-income countries. PLoS Med. 2015;12(3):e1001795.

28. Méndez-Sánchez N, Paraná R, Cheinquer H, et al. Latin American Association for the Study of the Liver recommendations on treatment of hepatitis C. Ann Hepatol. 2014;13 (Suppl 2):s4-s66.

29. Sánchez-Ávila JF, Dehesa-Violante M, Méndez-Sánchez N, et al. Mexican consensus on the diagnosis and management of hepatitis C infection. Ann Hepatol. 2015; 14 (Suppl 1):5-48.

30. Botero RC, Tagle M. New therapies for hepatitis C: Latin American perspectives. Clin Liv Dis. 2015;5(1):8-10.

31. AASLD/IDSA HCV Guidance Panel. Hepatitis C guidance: AASLDIDSA recommendations for testing, managing, and treating adults infected with hepatitis C virus. Hepatology. 2015;62(3):932-954.

32. Thomas DL, Thio CL, Martin MP, et al. Genetic variation in IL28B and spontaneous clearance of hepatitis C virus. Nature. 2009;461(7265):798-801.

33. Prokunina-Olsson L, Muchmore B, Tang W, et al. A variant upstream of IFNL3 (IL28B) creating a new interferon gene IFNL4 is associated with impaired clearance of hepatitis C virus. Nat Genet. 2013;45(2):164-171.

34. Aka PV, Kuniholm MH, Pfeiffer RM, et al. Association of the IFNL4- $\Delta \mathrm{G}$ allele with impaired spontaneous clearance of hepatitis $\mathrm{C}$ virus. J Infect Dis. 2014;209(3):350-354.

35. Gonzalez-Aldaco K, Rebello Pinho JR, Roman S, et al. Association with spontaneous hepatitis $\mathrm{C}$ viral clearance and genetic differentiation of IL28B/IFNL4 haplotypes in populations from Mexico. PLoS One. 2016;11(1):e0146258.

36. Mangia A, Thompson AJ, Santoro R, et al. An IL28B polymorphism determines treatment response of hepatitis $C$ virus genotype 2 or 3 patients who do not achieve a rapid virologic response. Gastroenterology. 2010;139(3):821-827.

37. Sarrazin C, Susser S, Doehring A, et al. Importance of IL28B gene polymorphisms in hepatitis $\mathrm{C}$ virus genotype 2 and 3 infected patients. J Hepatol. 2011;54(3):415-421.

38. Rallon NI, Naggie S, Benito JM, et al. Association of a single nucleotide polymorphism near the interleukin-28B gene with response to hepatitis $\mathrm{C}$ therapy in $\mathrm{HIV} /$ hepatitis $\mathrm{C}$ virus-coinfected patients. AIDS. 2010;24(8):F23-F29.

39. Mangia A, Thompson AJ, Santoro R, et al. Limited use of interleukin 28B in the setting of response-guided treatment with detailed ontreatment virological monitoring. Hepatology. 2011;54(3):772-780.

40. LiY, Yang L, Sha K, Liu T, Zhang L. Correlation of interferon-lambda 4 ss 469415590 with the hepatitis $C$ virus treatment response and its comparison with interleukin $28 \mathrm{~b}$ polymorphisms in predicting a sustained virological response: a meta-analysis. Int J Infect Dis. 2016;53:52-58.

41. Muir AJ, Gong L, Johnson SG, et al; Clinical Pharmacogenetics Implementation Consortium (CPIC). Clinical Pharmacogenetics Implementation Consortium (CPIC) guidelines for IFNL3 (IL28B) genotype and PEG interferon- $\alpha$-based regimens. Clin Pharmacol Ther. 2014;95(2):141-146.

42. Serfaty L. How to optimize current therapy in hepatitis $\mathrm{C}$ virus genotype 1 patients. Predictors of response to interferon-based therapy with second wave direct acting antivirals. Liver Int. 2015;35 (Suppl 1):18-20.

43. Meissner EG, Bon D, Prokunina-Olsson L, et al. IFNL4- $\Delta$ G genotype is associated with slower viral clearance in hepatitis $\mathrm{C}$, genotype-1 patients treated with sofosbuvir and ribavirin. J Infect Dis. 2014;209(11):1700-1704.

44. Akamatsu S, Hayes $\mathrm{CN}$, Ochi $\mathrm{H}$, et al. Association between variants in the interferon lambda 4 locus and substitutions in the hepatitis $\mathrm{C}$ virus non-structural protein 5A. J Hepatol. 2015;63(3):554-563.

45. Itakura J, Kurosaki M, Takada H, et al. Naturally occurring, resistanceassociated hepatitis $\mathrm{C}$ virus NS5A variants are linked to interleukin-28B genotype and are sensitive to interferon-based therapy. Hepatol Res. 2015;45(10):E115-E121

46. Peiffer KH, Sommer L, Susser S, et al. Interferon lambda 4 genotypes and resistance-associated variants in patients infected with hepatitis $\mathrm{C}$ virus genotypes 1 and 3. Hepatology. 2016;63(1):63-73.
47. Stättermayer AF, Scherzer T, Beinhardt S, Rutter K, Hofer H, Ferenci P. Review article: genetic factors that modify the outcome of viral hepatitis. Aliment Pharmacol Ther. 2014;39(10):1059-1070.

48. Tanaka Y, Kurosaki M, Nishida N, et al. Genome-wide association study identified ITPA/DDRGK1 variants reflecting thrombocytopenia in pegylated interferon and ribavirin therapy for chronic hepatitis $\mathrm{C}$. Hum Mol Genet. 2011;20(17):3507-3516.

49. Thompson A, Fellay J, Patel K, et al. Variants in the ITPA gene protect against ribavirin-induced hemolytic anemia and decrease the need for ribavirin dose reduction. Gastroenterology. 2010;139(4):1181-1189.

50. D'Avolio A, Cusato J, De Nicolò A, Allegra S, Di Perri G. Pharmacogenetics of ribavirin-induced anemia in HCV patients. Pharmacogenomics. 2016;17(8):925-941.

51. Kurosaki M, Tanaka Y, Nishida N, et al. Model incorporating the ITPA genotype identifies patients at high risk of anemia and treatment failure with pegylated-interferon plus ribavirin therapy for chronic hepatitis $\mathrm{C}$. J Med Virol. 2013;85(3):449-458.

52. Akamatsu S, Hayes CN, Tsuge M, et al. Ribavirin dose reduction during telaprevir/ribavirin/peg-interferon therapy overcomes the effect of the ITPA gene polymorphism. J Viral Hepat. 2015;22(2):166-174.

53. Reich D, Patterson N, Campbell D, et al. Reconstructing native American population history. Nature. 2012;488(7411):370-374.

54. Fridman C, Gonzalez RS, Pereira AC, Cardena MM. Haplotype diversity in mitochondrial DNA hypervariable region in a population of southeastern Brazil. Int J Legal Med. 2014;128(4):589-593.

55. Corach D, Lao O, Bobillo MC, et al. Inferring continental ancestry of argentineans from autosomal, Y-chromosomal and mitochondrial DNA. Ann Hum Genet. 2010;74(1):65-76.

56. de Saint Pierre M, Bravi CM, Motti J, et al. An alternative model for the early peopling of southern South America revealed by analyses of three mitochondrial DNA haplogroups. PLoS One. 2012;7(9):e43486.

57. Heinz T, Cárdenas JM, Álvarez-Iglesias V, et al. The genomic legacy of the transatlantic slave trade in the yungas valley of Bolivia. PLoS One. 2015;10(8): 0134129

58. Sandoval JR, Lacerda DR, Acosta O, et al. The genetic history of peruvian quechua-lamistas and chankas: uniparental DNA patterns among autochthonous Amazonian and Andean Populations. Ann Hum Genet. 2016;80(2):88-101.

59. Cárdenas JM, Heinz T, Pardo-Seco J, et al. The multiethnic ancestry of Bolivians as revealed by the analysis of Y-chromosome markers. Forensic Sci Int Genet. 2015;14:210-218.

60. González-Sobrino BZ, Pintado-Cortina AP, Sebastián-Medina L, et al. Genetic diversity and differentiation in Urban and Indigenous populations of Mexico: patterns of mitochondrial DNA and Y-chromosome lineages. Biodemography Soc Biol. 2016;62(1):53-72.

61. Homburger JR, Moreno-Estrada A, Gignoux CR, et al. Genomic insights into the ancestry and demographic history of South America. PLoS Genet. 2015;11(12):e1005602.

62. Heinz T, Alvarez-Iglesias V, Pardo-Seco J, et al. Ancestry analysis reveals a predominant Native American component with moderate European admixture in Bolivians. Forensic Sci Int Genet. 2013;7(5): $537-542$.

63. Vullo C, Gomes V, Romanini C, et al. Association between Y haplogroups and autosomal AIMs reveals intra-population substructure in Bolivian populations. Int J Legal Med. 2015;129(4):673-680.

64. Altshuler DM, Gibbs RA, Peltonen L, et al; International HapMap 3 Consortium. Integrating common and rare genetic variation in diverse human populations. Nature. 2010;467(7311):52-58.

65. Suarez-Kurtz G. Pharmacogenetics in the brazilian population. Front Pharmacol. 2010;1:118.

66. Delvaux N, Costa VD, Costa MM, et al. Inosine triphosphatase allele frequency and association with ribavirin-induced anaemia in Brazilian patients receiving antiviral therapy for chronic hepatitis C. Mem Inst Oswaldo Cruz. 2015;110(5):636-643.

67. Ridruejo E, Solano A, Marciano S, et al. Genetic variation in interleukin28B predicts SVR in hepatitis C genotype 1 Argentine patients treated with PEG IFN and ribavirin. Ann Hepatol. 2011;10(4):452-457. 
68. Venegas M, Villanueva RA, Gonzalez K, Brahm J. IL28B polymorphisms associated with therapy response in Chilean chronic hepatitis C patients. World J Gastroenterol. 2011;17(31):3636-3639.

69. Ferreira PR, Santos C, Cortes R, et al. Association between IL28B gene polymorphisms and sustained virological response in patients coinfected with HCV and HIV in Brazil. J Antimicrob Chemother. 2012;67(2):509-510.

70. Martinez-Gomez LE, Chavez-Tapia NC, Burguete-Garcia AI, et al. IL28B polymorphisms predict the response to chronic hepatitis C virus infection treatment in a Mexican population. Ann Hepatol. 2012;11(6):876-881.

71. Alves CF, Grott CS, Lunge VR, et al. Interferon lambda 4 (IFNL4) gene polymorphism is associated with spontaneous clearance of $\mathrm{HCV}$ in HIV-1 positive patients. Genet Mol Biol. 2016;39(3):374-379.

72. Sixtos-Alonso MS, Avalos-Martinez R, Sandoval-Salas R, et al. A genetic variant in the interleukin $28 \mathrm{~B}$ gene as a major predictor for sustained virologic response in chronic hepatitis $\mathrm{C}$ virus infection. Arch Med Res. 2015;46(6):448-453.

73. Galvan CA, Elbarcha OC, Fernandez EJ, Beltramo DM, Soria NW. Distribution of polymorphisms in cytochrome P450 2B6, histocompatibility complex P5, chemokine coreceptor 5, and interleukin $28 \mathrm{~B}$ genes in inhabitants from the central area of Argentina. Genet Test Mol Biomarkers. 2012;16(2):130-133.

74. Soza A, Lopez-Lastra M. IL28B Polymorphisms among Latin American HCV patients. Curr Hepatitis Rep. 2013;12(4):276-279.

75. Trinks J, Hulaniuk ML, Caputo M, et al. Distribution of genetic polymorphisms associated with hepatitis $\mathrm{C}$ virus (HCV) antiviral response in a multiethnic and admixed population. Pharmacogenomics J. 2014;14(6): 549-554.

76.Trinks J, Hulaniuk ML, Caputo M, et al. Distribución de polimorfismos de nucleótido simple (SNPs) predictores de la respuesta al tratamiento antiviral en la infección crónica por el virus de la hepatitis $\mathrm{C}(\mathrm{HCV})$ en las distintas regiones geográficas de Argentina [Distribution of single-nucleotide polymorphisms (SNPs) predictive of antiviral treatment response in hepatitis $\mathrm{C}$ virus (HCV) chronic infection in different geographic regions in Argentina]. Medicina (B Aires). 2014;74 (Suppl 3):S117-S118. Spanish.
77. Cavalcante LN, Abe-Sandes K, Angelo AL, et al. IL28B polymorphisms are markers of therapy response and are influenced by genetic ancestry in chronic hepatitis $\mathrm{C}$ patients from an admixed population. Liver Int. 2012;32(3):476-486.

78. de Seixas Santos Nastri AC, de Mello Malta F, Diniz MA, et al. Association of IFNL3 and IFNL4 polymorphisms with hepatitis $\mathrm{C}$ virus infection in a population from southeastern Brazil. Arch Virol. 2016; 161(6):1477-1484.

79. Chidi AP, Rogal S, Bryce CL, et al. Cost-effectiveness of new antiviral regimens for treatment-naïve U.S. veterans with hepatitis C. Hepatology. 2016;63(2):428-436.

80. Najafzadeh M, Andersson K, Shrank WH, et al. Cost-effectiveness of novel regimens for the treatment of hepatitis $\mathrm{C}$ virus. Ann Intern Med. 2015;162(6):407-519.

81. Edwards DJ, Coppens DG, Prasad TL, Rook LA, Iyer JK. Access to hepatitis C medicines. Bull World Health Organ. 2015;93(11): 799-805.

82. Chu TW, Kulkarni R, Gane EJ, et al. Effect of IL28B genotype on early viral kinetics during interferon-free treatment of patients with chronic hepatitis C. Gastroenterology. 2012;142(4):790-795.

83. Monto A, Ryan J. Is IL28B genotype associated with more than one aspect of viral clearance? Hepatology. 2012;56(6):2414-2416.

84. European Association for the Study of the Liver. EASL Practice Guidelines: management of hepatitis C virus infection. J Hepatol. 2014;60(2): 392-420.

85. Italian Association for the Study of the Liver (AISF). Triple therapy with first-generation protease inhibitors for patients with genotype 1 chronic hepatitis C: recommendations of the Italian association for the study of the liver (AISF). Dig Liver Dis. 2014;46(1):18-24.

86. Pearlman BL, Ehleben C. Hepatitis C genotype 1 virus with low viral load and rapid virologic response to peginterferon/ribavirin obviates a protease inhibitor. Hepatology. 2014;59(1):71-77.

87. Andriulli A, Nardi A, Di Marco V, et al. An a priori prediction model of response to peginterferon plus ribavirin dual therapy in naïve patients with genotype 1 chronic hepatitis C. Dig Liver Dis. 2014;46(9): 818-825.
Pharmacogenomics and Personalized Medicine

\section{Publish your work in this journal}

Pharmacogenomics and Personalized Medicine is an international, peerreviewed, open access journal characterizing the influence of genotype on pharmacology leading to the development of personalized treatment programs and individualized drug selection for improved safety, efficacy and sustainability. This journal is indexed on the American Chemical

\section{Dovepress}

Society's Chemical Abstracts Service (CAS). The manuscript management system is completely online and includes a very quick and fair peer-review system, which is all easy to use. Visit http://www.dovepress. com/testimonials.php to read real quotes from published authors. 